Ethiopian Journal of Environmental Studies and Management EJESM Vol. 5 No. 42012

\title{
BASE CATION LEACHING FROM THE CANOPY OF A RUBBER (HEVEA BRASILIENSIS WILLD. MUELL-ARG) PLANTATION AT IKENNE, SOUTH WEST NIGERIA \\ ${ }^{*}$ ADEDEJI, 0.H. ${ }^{1}$ and GBADEGESIN, A.S. ${ }^{2}$ \\ http://dx.doi.org/10.4314/ejesm.v5i4.7
}

Received 10th January 2012; accepted 11th August 2012

\begin{abstract}
Base cations are essential to the sustainability of forest ecosystems. They are important for neutralizing the acidifying effects of atmospheric deposition. There is the need for in-depth understanding of base cation depletion and leaching from forest canopy. This is important particularly due to the increasing acidification and anthropogenic influences that alter biogeochemistry of the ecosystems. Availability and leaching of base cations $\left(\mathrm{Ca}^{2+}, \mathrm{Na}^{+}, \mathrm{P}\right.$, and $\mathrm{K}^{+}$) from the tree canopies were examined in two rubber (Hevea brasiliensis Willd. Muell-Arg) stands (40- and 15-year-old) in southwestern part of Nigeria. The chemical composition of throughfall in the area was dominated by calcium. Concentrations of $\mathrm{Ca}^{2+}, \mathrm{Na}^{+}, \mathrm{P}$, and $\mathrm{K}^{+}$were relatively high throughout the sampling periods. Significant differences $(P<0.05)$ were observed between precipitation and throughfall in concentrations of nutrient elements, and the enrichment occurred within the rubber plantation for all the nutrient elements. $\mathrm{Ca}^{2+}$ is mainly from precipitation, while over $70 \%$ of total K and total $\mathrm{Mg}$ were probably leach from canopy. Total annual nutrient returns via throughfall for the 15-year-old stand were 28.39, 4.49, 38.9, and 3.54 $\mathrm{kg} \mathrm{ha}$ year ${ }^{-1}$ for $\mathrm{Ca}^{2+}, \mathrm{Mg}^{2+}, \mathrm{K}^{+}$and $\mathrm{Na}^{+}$respectively, while that of the 40-year-old stand were 22.7, 3.64, 36.3, and $3.17 \mathrm{~kg} \mathrm{ha} \mathrm{year}^{-1}$ for $\mathrm{Ca}^{2+}, \mathrm{Mg}^{2+}, \mathrm{K}^{+}$and $\mathrm{Na}^{+}$respectively.
\end{abstract}

Keywords: Agroecosystem; atmospheric deposition; base cations, Hevea brasiliensis; nutrient cycling, throughfall,

\section{Introduction}

One of the major pathways by which atmospheric depositions can alter and damage forests is base cation depletion due to increasing soil acidity. Base cation depletion induced by atmospheric deposition has a major detrimental effect on nutrient cycling and forest health (Dean, 2002; Likens et al., 1996; Lawrence and Fernandez, 1993; Zhang et al., 2006a). Base cations are nutrients for forest ecosystems and vegetation and are thus of importance for the sustainability of ecosystems (Lindberg et al., 1986; Weathers et al., 2001). Base cations such as $\mathrm{Ca}^{2+}, \mathrm{P}$, and $\mathrm{K}^{+}$are the most prevalent, exchangeable and weak acid cations in the soil and generally originates from combination of wind erosion of soils, agricultural tillage practices, and traffic on unpaved roads (Draaijers et al., 1997). Base cations also occur in the air in the particulate phase and in precipitation, and are largely dissolved and occur as ions.

Input of base cation counteracts the acidification effects as it increases the base cation pool in the soil and, if associated with carbonates or oxides, they add alkalinity to the soil (Draaijers et al., 1997; Gorham, 1994; Westling and Lővblad, 2004). However, loss of base cations from forest soils can be accelerated by acid rain, by forest regrowth following harvest removals, and by declining inputs of base cations from atmospheric deposition. Cation leaching from tree canopy could affect physiological processes, damage flowering and dormancy patterns, and make plants more vulnerable to diseases and the effects of freezing (DeHayes et al., 1999; Lin et al., 2001; Wilby, 1997; Zhang et al., 2006c).

Monitoring forested throughfall may be a useful technique to estimate the amount of dry deposition to the forest stands provided that i) the pollutants are not taken up irreversibly by canopy and ii) canopy leaching of compound taken up by roots and transported to the leaves is negligible ( Lindberg et al., 1990; Zhang et al., 2006b). Reliable data on base cation leaching is thus of importance in forest and 
ecosystem management and has been measured and well documented many European North American, and Asian sites (Lovett et al., 1996; Liu et al., 2002; Nelson, 2002; Staelens et al., 2005). However, this is not true of most tropical forest ecosystem that is noted for low base saturation in soils, high humidity, and relatively short dry periods between rain events. For most areas, the data on base cation deposition and leaching from forest canopy are at present uncertain.

This study is focused on the examination of the relationships between atmospheric deposition and base cation leaching in a rubber (Hevea brasiliensis Willd. Muell-Arg) plantation agroecosystem in south western part of Nigeria. The specific objectives of study were to $(i)$ evaluate the base cation concentration and fluxes in bulk open precipitation and throughfall in both dry and wet seasons, (ii) quantify base cation leaching from the canopy relative to the canopy's nutrient content, (iii) identify any seasonal variation in base cation leaching from the rubber canopy, and (iv) examine variations in base cation leaching in two different rubber age stands to ascertain the influence of age stands on base cation leaching.

\section{Materials and Method \\ Study Area}

The present study was carried out between July 2005 to June 2006, in an old rubber plantation at Ikenne, southwestern Nigeria Latitude $6^{\circ} 50^{\prime}$ to $6^{\circ} 54^{\prime} \mathrm{N}$ and Longitude $3^{\circ} 40^{\prime}$ to $3^{\circ} 45^{\prime} \mathrm{E}$ (see Fig. 1) and about $110 \mathrm{~m}$ above sea level. The vegetation type of the area acquire for the establishment of the rubber plantation in the early 1960s previously consisted of trees species such as Isotonia boonei, Cola gigantea Antiaris africana, Pentaclethra macrophylla, and Elaeis guineensis (Gbadegesin, 1987). Mean annual precipitation in the area was between 1,500 $\mathrm{mm}$ and $1,750 \mathrm{~mm}$ with a maximum in July and a mean annual temperature of $27^{\circ} \mathrm{C}$.

The soils of the area is ultisols, which are considered marginal for agricultural production since the soils are highly weathered, low in cation exchange capacity (CEC), base saturation and $\mathrm{pH}$ (West et al., 1998). The texture of the surface soils is usually loamy and sandy, becoming heavier with clay at greater depths, frequently with gravel layer at $30-60 \mathrm{~cm}$. the CEC varies from $1.3 \mathrm{Cmol} / \mathrm{kg}$ to $17.3 \mathrm{Cmol} / \mathrm{kg}$ in the topmost layer (Aweto, 1987) and the soil $\mathrm{pH}$ values ranges from 6.5 to 6.7 in the topsoil. However, a rapid decline in $\mathrm{pH}$ and aluminium toxicity occurs with depth and this can lead to serious fall in productivity after only a few years of cultivation (Periaswamy and Ashaye, 1982). The soil is characterised by low levels of soil organic matter, exchangeable cations ( $\mathrm{Ca}, \mathrm{Mg}$, $\mathrm{K}$ and effective $\mathrm{CEC}, \mathrm{pH}, \mathrm{N}, \mathrm{P}$ and high level of total acidity $(\mathrm{Al}+\mathrm{H})$ and exchangeable $\mathrm{Mn}$ (Amusan et al., 2005). Cation exchange capacity (CEC) varies from $1.3 \mathrm{me} / 100 \mathrm{gm}$ to $17.3 \mathrm{me} / 100 \mathrm{gm}$ in the topmost layer (Aweto, 1987). Of the 1,111 hectares of land acquired for the rubber plantation, effective rubber trees presently cover about 500ha of which about $98 \%$ are old and not economically viable. The Rubber Research Institute of Malaysia (RRIM 501) clones were planted at different years (1961, 1991, and 2000) per hectare in different block within the plantation. There is an average of 450 trees per hectare in each rubber stands. 


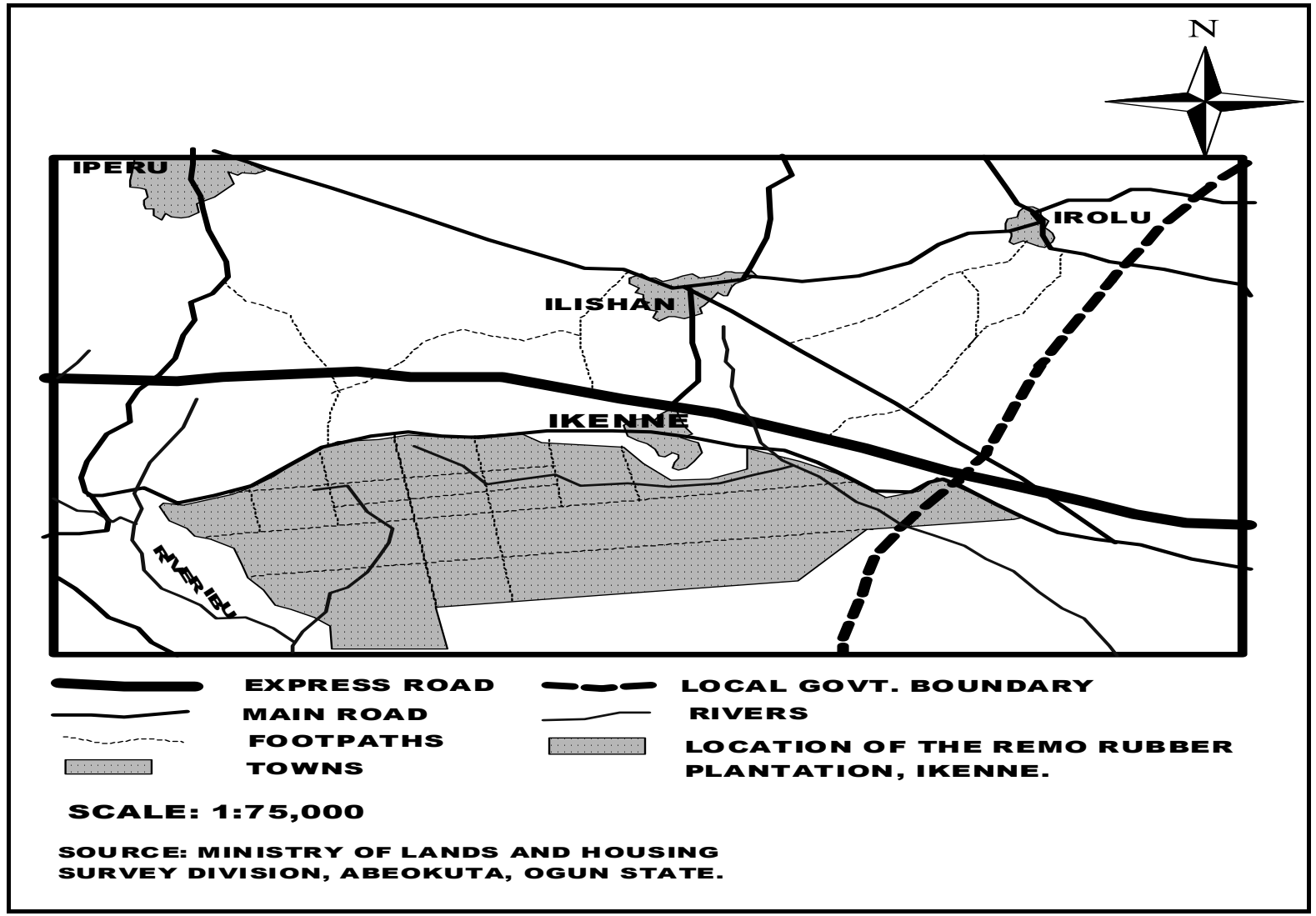

Figure 1 Location of study Area

\section{Sampling Design}

The two rubber age stands ((40- and 15year-old).) selected for this study were located within $200 \mathrm{~m}$ of each other and this allows for comparison between the different age stands. Two replicate experimental plots were established in each rubber age stands on flat surface, and each experimental plot $(50 \times 20 \mathrm{~m})$ comprises a central zone, surrounded by a buffer zone approximately 1 metre wide and each plot. Eight throughfall collectors were randomly distributed in each plot. The funneltype gauges used for the purpose of this study were based on the design by Lawrence and Fernandez (1993) and adopted by Nelson (2002) because of its simplicity and ease of installation and manipulation. Each funnel had a 6-cm vertical tip and a $45{ }^{\circ} \mathrm{C}$ slope to minimize splashing (Liu et al., 2002). The funnels type collectors were installed 2-2.5 m from each other, avoiding trunks. The collectors were placed under vegetation canopies $1.5 \mathrm{~m}$ above the ground and arranged in a line. Throughfall collectors were placed within the plots in such ways to avoid edge effects.

All leaves and branches $1 \mathrm{~m}$ above the funnels were cleared to reduce the direct impact of plants. De-ionized water (DI) rinsed polywool plug was inserted into the neck of each funnel to exclude insect frass and plant litter from the collection bottle. Five collectors were randomly distributed in open ground adjacent to the rubber age stands to collect incident precipitation (bulk precipitation). The five collectors were used to ensure that any samples, which were clearly polluted, could be discarded without the loss of the whole sample for the sampling period (Thimonier, 1998; Mosello et al., 2002). Because volume and chemistry differed among the five precipitation collectors by less than $5 \%$, samples from the collectors were combined (Thimonier, 1998). In order to check on possible contamination on the site, field blank tests were carried out at least once every three 
month. For this purpose, samples of 50-100 ml deionized water was poured into the sample collector at the time of collection in days without precipitation, and subjected to the same procedure as an ordinary precipitation sample (Sevruk, 1989).

\section{Sample collection and laboratory analysis}

Throughfall and bulk precipitation samples were collected bi-weekly from the two rubber stands between July 2005 and June 2006. Throughfall and bulk precipitation volume was measured in the field and a 500 $\mathrm{mL}$ subsample collected, and the remainder of each sample was used to clean the collectors, tubing, and storage jars. At every three months, the collectors are washed with acid (Sevruk, 1989). Samples were taken to the laboratory in pre-labelled $120 \mathrm{~cm}^{3}$ capacity snap lid collection bottles and immediately frozen and stored at $4{ }^{\circ} \mathrm{C}$. The analyses of cations $\left(\mathrm{Na}^{+}, \mathrm{Ca}^{2+}, \mathrm{Mg}^{2+}\right.$, and $\left.\mathrm{K}^{+}\right)$in filtered samples $(0.45 \mu \mathrm{m}$ sterilized filter paper $)$ were determined by flame atomic absorption spectrometry ((AAS Atomic Absorption Spectrum- 932, GBC Scientific Equipment pty. Ltd, Australia). All tests were carried out at the Institute for Agricultural Research and Training, (IAR\&T) Ibadan, Nigeria.

\section{Statistical Analyses}

Differences in ion concentrations and fluxes between precipitation and throughfall and between the two rubber age stands were estimated using one-way ANOVA. The statistical analyses were performed using the SPSS for windows Version 11.0 (SPSS, 2003).

\section{Results and Discussion}

Rainfall and throughfall chemical composition

The throughfall $\mathrm{pH}$ increased significantly $(p<0.05)$ compared to the bulk precipitation ranging from 5.83 to 6.53 (Table 1). This was influenced by the leaching of base cations from the canopy of the rubber trees. Concentrations of the cations were relatively high throughout the sampling periods with calcium concentration dominating others in the throughfall. Total annual nutrient inputs reaching the rubber floors in each stand indicated that canopy leaching occurs for all the cations at different rates. About $91 \%$ of the total annual $\mathrm{K}^{+}, 52 \%$ of $\mathrm{Ca}^{2+}$, and $67 \%$ of the total annual $\mathrm{Mg}^{2+}$ throughfall input was due to canopy leaching. Table 1 shows volume-weighted mean concentrations of the cations in both precipitation and throughfall samples in the rubber stands

Table 1 Volume-weighted mean concentrations $( \pm$ SD) in precipitation and throughfall in rubber (Hevea brasiliensis) plantation agroecosystem at Remo Rubber Plantation, Ikenne, SW Nigeria in dry season $(n=12)$ and wet season $(n=18)$. Nutrient concentrations in throughfall vs. precipitation are compared in analysis of variance.

\begin{tabular}{|c|c|c|c|c|c|c|c|}
\hline Items & Season & $\mathbf{p H}$ & $\mathrm{Ca}^{2+}$ & $\mathbf{M g}^{2+}$ & $\begin{array}{l}\mathrm{K}^{+} \\
\mu \rho L^{-1}\end{array}$ & $\mathbf{N a}^{+}$ & $\mathbf{H}^{+}$ \\
\hline & Dry & 6.24 & $14.95^{\mathrm{a}}$ & $0.13^{\mathrm{a}}$ & $1.58^{\mathrm{a}}$ & $2.82^{\mathrm{a}}$ & $0.11^{\mathrm{a}}$ \\
\hline Bulk & Wet & 6.39 & $17.29^{\mathrm{b}}$ & $0.12^{\mathrm{a}}$ & $1.93^{\mathrm{b}}$ & $2.91^{\mathrm{a}}$ & $0.13^{\mathrm{a}}$ \\
\hline Precipitation & Annual & 6.32 & $15.85^{\mathrm{a}}$ & 0.12 & $1.76^{\mathrm{b}}$ & $2.87^{\mathrm{a}}$ & $0.12^{\mathrm{a}}$ \\
\hline 40-Year-old & Dry & 6.22 & $15.42^{\mathrm{a}}$ & $0.11^{\mathrm{a}}$ & $1.67^{\mathrm{a}}$ & $2.95^{\mathrm{b}}$ & $0.11^{\mathrm{a}}$ \\
\hline \multirow[t]{2}{*}{ Throughfall } & Wet & 6.50 & $18.09^{\mathrm{b}}$ & $0.12^{\mathrm{a}}$ & $1.94^{\mathrm{c}}$ & $3.09^{\mathrm{b}}$ & $0.12^{\mathrm{a}}$ \\
\hline & Annual & 6.37 & $16.75^{\mathrm{b}}$ & $0.11^{\mathrm{a}}$ & $1.81^{\mathrm{b}}$ & $3.02^{\mathrm{b}}$ & $0.11^{\mathrm{a}}$ \\
\hline 15-Year-old & Dry & 6.29 & $16.58^{\mathrm{a}}$ & $0.12^{\mathrm{a}}$ & $1.69^{\mathrm{a}}$ & $2.90^{\mathrm{a}}$ & $0.11^{\mathrm{a}}$ \\
\hline \multirow[t]{2}{*}{ Throughfall } & Wet & 6.47 & $17.95^{\mathrm{b}}$ & $0.15^{\mathrm{a}}$ & $2.12^{\mathrm{b}}$ & $3.02^{\mathrm{a}}$ & $0.12^{\mathrm{a}}$ \\
\hline & Annual & 6.38 & $17.27^{\mathrm{b}}$ & $0.13^{\mathrm{a}}$ & $1.91^{\mathrm{b}}$ & $2.96^{\mathrm{a}}$ & $0.11^{\mathrm{a}}$ \\
\hline
\end{tabular}

Different letter between solution compositions in the columns indicate significant differences at the $95 \%$ level of confidence. 
The high leaching flux of base cations under the rubber stands is partly due to calcareous parent materials from which weathering frees large amounts of base cations. In most cases, base cation leaching is higher than deposition, and this show that the acid input is almost completely buffered by the release of base cations from the tree canopy. The enrichment of elements in throughfall has been ascribed to the dissolution and washout of atmospheric material deposited on canopy (Laclau et al., 2003; Levia and Frost, 2006; Liu et al., 2002;

Parker, 1983) or due to exchange between rainfall and elements in internal plant parts (Marquez and Ranger, 1997). Throughfall is enriched in sodium probably because of the marine influence (tropical air mass from the Atlantic Ocean), which is about $70 \mathrm{~km}$ away from the study site. In studies comparing throughfall with deposition measurements, it is generally concluded that for sodium, canopy exchange is negligible (Erisman et al., 2002). $\mathrm{Ca}^{2+}$ is mainly from precipitation, while over $70 \%$ of total $\mathrm{K}$ and total $\mathrm{Mg}$ were probably leach from canopy.

Table 2 Seasonal and annual input of nutrients via bulk precipitation and throughfall (All Stands) in rubber (Hevea brasiliensis) plantation agroecosystem at Remo Rubber Plantation, Ikenne, SW Nigeria in dry season $(\mathrm{n}=12)$ and wet season $(\mathrm{n}=18)$.

\begin{tabular}{|c|c|c|c|c|c|}
\hline \multirow{2}{*}{$\begin{array}{l}\text { Items } \\
\text { Bulk }\end{array}$} & \multirow{2}{*}{$\begin{array}{l}\text { Season } \\
\text { Dry }\end{array}$} & $\mathrm{Ca}^{2+}$ & \multicolumn{2}{|c|}{$\underset{k g \text { ha year }}{\mathrm{Mg}^{2+}} \mathrm{K}^{+}$} & $\mathrm{Na}^{+}$ \\
\hline & & 0.83 & 0.16 & 0.28 & 0.15 \\
\hline \multirow[t]{2}{*}{ Precipitation } & Wet & 9.95 & 1.52 & 1.85 & 3.32 \\
\hline & Total & 10.78 & 1.68 & 2.13 & 3.47 \\
\hline 40-year-old & Dry & 0.92 & 0.15 & 3.78 & 0.15 \\
\hline \multirow[t]{2}{*}{ Throughfall } & Wet & 21.73 & 3.49 & 32.5 & 3.02 \\
\hline & Total & 22.65 & 3.64 & 36.3 & 3.17 \\
\hline 15-year-old & Dry & 1.56 & 0.29 & 3.31 & 0.27 \\
\hline \multirow[t]{2}{*}{ Throughfall } & Wet & 26.83 & 4.20 & 35.6 & 3.28 \\
\hline & Total & 28.39 & 4.49 & 38.9 & 3.54 \\
\hline
\end{tabular}

As can be seen from Table 2., the total annual nutrient returns via throughfall for the 15 -year-old stand were $28.39,4.49,38.9$, and $3.54 \mathrm{~kg}$ ha year ${ }^{-1}$ for $\mathrm{Ca}^{2+}, \mathrm{Mg}^{2+}, \mathrm{K}^{+}$and $\mathrm{Na}^{+}$ respectively, while that of the 40-year-old stand were $22.7,3.64,36.3$, and $3.17 \mathrm{~kg}$ ha year ${ }^{-1}$ for $\mathrm{Ca}^{2+}, \mathrm{Mg}^{2+}, \mathrm{K}^{+}$and $\mathrm{Na}^{+}$ respectively. Inputs of these elements in the different rubber stands are higher in the 15year-old stand than the 40-year- old stand. Base cations are typically leached from the tree foliage and foliar uptake of $\mathrm{H}^{+}$buffer anthropogenic acidity and promote foliar leaching of cations to maintain charge balance.

\section{Conclusion}

Base cation species show large differences between throughfall and bulk deposition because of canopy exchange. Base cations $\left(\mathrm{Ca}^{2+}, \mathrm{K}^{+}, \mathrm{Na}^{+}\right.$, and $\left.\mathrm{Mg}^{2+}\right)$ amount and fluxes are increased in throughfall. Inputs of base cations in the different rubber stands are higher in the 15-year-old stand than the 40year- old stand. Data on base cation deposition and leaching are important for studying the effects of acidification of agroecosystem. Deposition levels sufficient to cause some damage to ecosystems have not being observed in the study area; however efforts should be geared towards forestalling any 
future occurrence in order to ensure sustainable agricultural development.

\section{Acknowledgment}

The work reported in this article is a part of post-graduate research undertaken in the Department of Geography, University of Ibadan, Ibadan Nigeria by Adedeji, O.H under the supervision of Professor A.S. Gbadegesin. We are grateful to Mr. Oladapo of the Institute of Agriculture, Research and Training (IAR\&T) Ibadan for the logistics and laboratory analyses of soil sample. Mr. Odufuwa B.O. for his invaluable suggestions and very helpful comments in correcting the manuscript

\section{References}

Aweto, A.O. (1987). Physical and Nutrient Status of Soils under Robber (Hevea Brasiliensis) of Different ages in SouthWestern, Nigeria. Agricultural Systems 23, 63-72.

Draaijers, G.P.J, Erisman, J., Spranger, T., and Wyers, G. (1997). The application of throughfall measurements for atmospheric deposition monitoring. Atmospheric Environment $30,3349-3368$

Erisman, J.W., Möls, J.J., Forteijn, P.B and Bakker, F.P. (2002). Throughfall monitoring at 4 sites in the Netherlands between 19912001. ECN--C-02-013, 1-26.

Gbadegesin, A. S. (1987): Aspect of Soil and Vegetation. In: Faniran A. et al. "Ago-Iwoye Region". Dept of Geography and Regional Planning, Ogun State University Ago-Iwoye. Rex Charles Publications. Ibadan

Laclau, J., Deleporte, P., Ranger, J., Bouillet, J, and Kazotti, G. (2003). Nutrient Dynamics throughout the Rotation of Eucalyptus Clonal Stands in Congo. Annals of Botany 91, 879-892. Retrieved June 152005 from erm.shtml http://www.aob.oupjournals.org/misc/t

Lawrence, G. B. and Fernandez, I. J. (1993). A reassessment of areal variability of throughfall deposition measurements. Ecological Applications 3, 473-480.

Levia Jr, D. F. and Frost, E. E. (2006). Variability of throughfall volume and solute inputs in wooded ecosystems. Progress in Physical Geography 30 (5), 605-632.

Lindberg, S. E., Lovett, G. M., Richter, D.D. and Johnson, D. W. (1986). Atmospheric deposition and canopy interactions of major ions in a forest. Science 231,141- 145. Liu, W., Fox, J.E.D. and Xu, Z. (2002). Nutrient fluxes in bulk precipitation, throughfall and stemflow in montane subtropical moist forest on Ailao Mountains in Yunnan, southwest China. Journal of Tropical Ecology 18, 527-548.

Marquez, R. and Ranger, J. (1997). Nutrient dynamics in a chronosequence of Douglas fir stands on the Beaujolais Mountains 1. Qualitative approach. Forest Ecology and Management. 91, 55-277.

Nelson, S.J. (2002). Determining atmospheric deposition inputs to two small watersheds at Acadia National Park. Technical Report NPS/BSO-RNR/NRTR/2002-8. National Park Service, Boston Support Office. Boston, MA.

Parker, G. G. (1983). Throughfall and stemflow in the forest nutrition cycle. Advance in Ecological Research 13, 57-133.

Sevruk, B. (1989). Reliability of Precipitation Measurement. In: B. Sevruk (ed.), Precipitation Measurement, Swiss Federal Institute of Technology (ETH), Zurich, 1319.

SPSS. (2003). Standard version. SPSS Inc. Chicago, Illinois

Staelens, J., De Schrijver, A., Van Avermaet, P., Genouw, G. and Verhoest, N. (2005). A comparison of bulk and wet-only deposition at two adjacent sites in Melle (Belgium). Atmospheric Environment 39, 7-15. Retrieved 06.22/05 from.

www.elsevier.com/locate/atmosenv.pdf

Thimonier, A. (1998). Measurement of atmospheric deposition under forest canopies: some recommendations for equipments and sampling design. Environmental Monitoring and Assessment. 52, 353-387.

Weathers. K.C., Lovett, G.M. and Lindberg, S.E. 2001. Atmospheric Deposition in Complex Terrain: Scaling Up to the Landscape at Acadia NP and Great Smoky Mountains NP. Proposal. 
Westling, O and Lővblad, G (Eds) (2004).

Emission, transport, deposition and effects of base cations in relation to acidification. Report from an UNECE LRTAP-ASTA-Nordic Council of Ministers workshop in Gothenburg November 2003.IVL. Report B1585, www.ivl.se under download reports.

Wilby, R. (ed.) (1997). Contemporary Hydrology: Toward Holistic Environmental Science. John Wiley and Son Ltd.

Zhang, F.Z., Zeng, G.M., Jiang, Y.M., Huang, G.H. Li, J.B., Yan, J.M., Tan, W., Xiang, R.J., and Zhang, X.L (2006a). Modelling and measurement of two-layer-canopy interception loss in a subtropical mixed forest of central
China. Hydrology and earth

System Sciences. 10, 65-77

Zhang, F.Z., Zeng, G.M., Jiang, Y.M., Yao, J.M., Huang, G.H. Li, Jiang, X.Y., Tan, W., Zhang, X.L., and Zong, M (2006b). Effects of weak acids on canopy leaching and uptake in a coniferous forest in central-south China. Water, Air, and Soil Pollution. 172: 39-55 Zhang, F.Z., Zeng, G.M., Jiang, Y.M., Du, C.Y., Huang, G.H., Yao, J.M., Zeng, M., Zhang, X.L., and Tan, W. (2006c). Seasonal dry deposition and canopy leaching of base cations in a sub-topical evergreen mixed forest, China. Silva Fennica 40(3): 417-428. 